\title{
Selection of magister learners in Nursing Science at the Rand Afrikaans University
}

\author{
A Botes, D.Cur, MA Philosophy, Department of Nursing, RAU
}

Data collection conducted by dr. Diana du Plessis (D.Cur)

\section{Abstract}

Selection of learners implies that candidates are assessed according to criteria with the purpose of selecting the most suitable learners for the course.

A magister qualification is on level $8 \mathrm{~A}$ of the National Qualifications Framework (NQF). The purpose of a magister qualification in Nursing is the development of advanced research, clinical, professional, managerial, educational, leadership and consultative abilities (knowledge, skills, values and attitudes) for the promotion of individual, family, group and community health.

From the above introduction it becomes clear that there is a high expectations of a person with a magister qualification. Such a person should be a specialist, scientist, leader and role model in the profession. A magister programme is human-power intensive as well as capital intensive for both the learner and higher education institutions. It is therefore important to select learners with the ability to achieve the outcomes of the programme. Limited research has been conducted on the selection of post graduate learners.
This leads to the question whether the current selection criteria (undergraduate mark and the mark in Research Methodology) are reasonable predictors of success for the magister programmes.

In order to answer this question, hypotheses with the following variables were formulated.

$\diamond \quad$ Achievement/ success in the magister programme as reflected by

$\diamond \quad$ The mark for the dissertation or mini-dissertation.

$\diamond \quad$ The level of input by the supervisor during the magister programme.

$\therefore \quad$ The quality of the research article reflecting the research in the magister programme.

$\diamond \quad$ Undergraduate mark

$\diamond \quad$ Mark for Research Methodology

In order to test the hypotheses a quantitative correlation design was used incorporating documented data of 74 magister graduates. Descriptive and inferential data analysis (Pearson's correlation coefficient, ANOVA and multivariate test) were used.

The findings showed Research Methodology to be the best indicator of success in the magister programmes.

\section{Introduction and Problem Statement}

A magister qualification is on level 8A of the National Qualifications Framework (NQF). The purpose of a magister qualification in Nursing is the development of advanced research, clinical, professional, managerial, educational, leadership and consultative abilities (knowledge, skills, values and attitudes) for the promotion of individual, family, group and community health (Department of Nursing, 1999).

A learner has some options for achieving a magister qualification in Nursing at the Rand Afrikaans University. The first option is to follow a lectured Nursing Science Magister Programme in one of the following specialisation fields, namely:

$\diamond \quad$ Medical and Surgical Nursing Science: Critical Care Nursing (General)

$\diamond \quad$ Psychiatric Nursing Science

$\diamond \quad$ Midwifery and Neonatal Nursing Science

The lectured component of the programme is followed by a research project (mini-dissertation).

The second option is a non-lectured (dissertation-based) magister programme in one of the following fields, namely: $\diamond \quad$ Ethos and Professional Practice

$\diamond \quad$ Community Nursing Science

$\diamond \quad$ Child Health Nursing Science

$\diamond \quad$ Medical and Surgical Nursing Science: Critical Care (General)

$\diamond \quad$ Midwifery and Neonatal Nursing Science

$\diamond \quad$ Psychiatric Nursing Science

Research Methodology is a fundamental, compulsory course for all magister programmes, with 32 credits. Learners are advised to do Research Methodology for non-qualification purposes, prior to registration for a magister programme. The inclusion of Research Methodology as part of a post graduate programme complies with international pre-requisites (American Association of Colleges in Nursing, 1990:3).

In order to qualify for a magister qualification the learner should demonstrate specific competencies (knowledge, skills, values and attitudes) to conduct and communicate a research project (in written and oral format) in a scientific manner. A person with a magister qualification in Nursing Science func- 
tions as a specialist, scientist, leader and role model.

Access into a magister programme requires the learner to have completed a Baccalaureate qualification on level seven (7) of the NQF with a minimum of 480 credits. The learner should have achieved a minimum of $65 \%$ in the undergraduate programme or Advanced Diploma in Nursing as related to the optional specialisation field. If a learner does not qualify with the before-mentioned criterion s/he can access a magister programme with a $60 \%$ in Research Methodology (on magister level). As part of the registration procedure the supervisor should testify that a learner is competent to complete a magister qualification.

From the above introduction it becomes clear that there is a high expectation of a person with a magister qualification. Such a person should be a specialist, scientist, leader and role model in the profession. A magister programme is humanpower intensive as well as capital intensive for both the learner and higher education institutions. It is therefore important to select learners with the ability to achieve the outcomes of the programme. Limited research has been conducted on the selection of postgraduate learners.

This leads to the question whether the current selection criteria (undergraduate mark and the mark in Research Methodology) are reasonable predictors of success for the magister programmes.

\section{Literature Review}

Four focus points should be considered with regard to the selection of magister learners. Firstly, the importance of selection of magister learners should be justified. Secondly, the concept of success in a magister programmes should be defined. Thirdly the criteria for assessment should be clarified, and finally, the prediction value of such criteria should be investigated. Each of these focus points will be addressed.

Selection of learners implies that candidates should be assessed according to criteria with the purpose of selecting the most suitable learners for the course (Robbins, 1982:120). Selection of learners has shortcomings as a result of the possible wastage of potentially successful candidates (Miller, 1970:140). To justify the importance of selection for magister learners the following points could be considered.

Selection of candidates is a predictive norm of the success of education as well as practice of the profession (Basson, 1981:13). The author hereby emphasises the benefits of selection for education as well as the practice of nursing. In order to present a dissertation ideas and findings should be substantiated with reasoned arguments and evidence (Barnes, 1995:100). At magister level, research requires a high degree of critical, analytical, logical, evaluative and problem-solving skills. It is therefore important to select a learner with the competencies to meet these demands. Magister programmes are human-power intensive and capital intensive for both the learner and the institution. To select the most suitable candidates therefore has advantages for both the learner and the institution. The qualified learner of a magister programme should be able to practice as a leader, specialist, scientist and role model in the nursing profession. It is important to en- sure the quality of nursing practice by selecting a candidate who will meet these demands.

To define success or failure in a magister programme is not easy. According to Entwistle and Wilson (1977:10), certain factors lead to success, namely:

$\diamond \quad$ Progress

$\diamond \quad$ Competence

$\diamond \quad$ Satisfaction

In order to describe a learner as successful, all these factors should relate harmoniously. The learner should progress satisfactorily towards graduation. It is important that a learner in a magister programme reaches the exit outcome within two years after registering for the programme. Research should be conducted independently under the supervision of a study leader. During supervision, the input level is also an important indicator of success.

The learner should be competent to perform and communicate a research project scientifically. The abilities of the learner to communicate the research project satisfactorily will be reflected by the average mark awarded by the supervisor and external examiners. Formal success criteria are based on numeral values attained during evaluation or examination (Entwistle \& Wilson, 1977:11). The learner's understanding of the research process will be reflected by the quality of the research article from the dissertation/mini-dissertation.

The before-mentioned statements support the description of success (dependant variables) in the magister programme for this study, namely:

$\diamond \quad$ The mark for the dissertation or mini-dissertation.

$\diamond \quad$ The level of input of the supervisor during the magister programme as described by the scale in table 1 .

$\diamond \quad$ The quality of the research article reflecting the research for the magister qualification as described by the scale in table 2 .

The third point of importance in the selection of magister learners is the selection criteria. Although little research has been conducted on selection of learner for post-graduate studies (Miller, 1977:132), the principles of selection and predictors for success in research in undergraduate studies can be used for this purpose.

Academic achievements are widely used as indicators for success in institution of higher education. Research indicates that grade point average is a significant factor in the prediction of success in undergraduate studies (Botes \& Du Plessis, 1989; Wing \& Wallach, 1971:15; Entwistle \& Wilson, 1977:18). There are, however, shortcomings in school achievement as a predictor of undergraduate success (Miller, 1970:132).

According to Eddins (1983) a significant relatedness can be found between study habits, as reflected by adequate and timely completion of assignments, regular class attendance and by asking questions in class, and success in graduate studies. Attempts were made to assess a learner's ability to adjust to the pressure and stress in higher education institutions (Wing \& Wallach,1971:11). The "one who can get started" is a simple way of describing a good learner (Barnes, 1995:1). Successful learners are those in control of their own lives and 
learning (Barnes, 1995:7). Signs of curiosity and an inquiring mind are good traits for potential researchers (Barnes, 1995:101).

Failing to comply with the requirements for a qualification could firstly be due to misjudging the requirements and secondly to not really wanting to study (Barnes, 1995:5). It is not good enough to study for a magister qualification because it is nice to have it. Motivation to study is vital for success (Barnes, 1995:5). The importance of hard work, effective study methods, intellectual competencies and motivation are selfevident success predictors (Entwistle \& Wilson, 1977:13). Internal motivation is reflected by an attitude of "learning for the learning sake" (Entwistle \& Wilson, 1977:30).

In order to qualify for postgraduate research, learners are required to possess a good (70\% and higher) honours degree (Miller, 1970:132). A study reported high grades in undergraduate study as not being significantly related to success at magister level. Social adjustment was directly related to the performance of $\mathrm{PhD}$ candidates. Although older learners are expected to have greater social responsibilities than younger learners, more aspects of their social life are vulnerable to maladjustment during studies.

Interview assessment of candidates' favourable or negative attitudes to post graduate studies failed to distinguish significantly between successful and unsuccessful learners. This implies that selective interviews achieve very little (Miller, 1970:132).

A trial period to assess the competencies of research candidates was proposed by Hudson (1965). However, in a sample of 85 , Whitehand (1966) found no correlation between the mark for the research project in the undergraduate course and success in post graduate studies. Most accounted for factors in the variance were indicative of the learners' favourable self-perception of their competencies and the desire to work autonomously, as well as their sense of responsibility (Miller, 1970:136)

In order to clarify the criteria for selection the following points from the above literature review are important. Academic achievements are widely used as selection criteria although one study reported no significant relation between grades in the undergraduate course and success at magister level. The selection policy for postgraduate learners at the Rand Afrikaans University also identifies the marks in the undergraduate course as a criterion for selection.

Further criteria from the literature review are study habits, motivation and responsibility. A trial period to assess the competencies of research candidates was also proposed. The mark for or achievement in Research Methodology at magister level can be viewed as a reflection of candidates' study habits, motivation and sense of responsibility. The recommendation that learners do Research Methodology before registering for a magister programme seems to be justified as a trial period to assess the competencies to conduct research.

The last point of importance, namely the influence of these criteria for predicting success in the magister programme will be reflected by the results of this study.

\section{Research purpose and objectives}

To describe the influence of selection criteria for magister learners based on the relatedness of the following variables, namely:

$\diamond \quad$ Achievement/success in the magister programme as reflected by

$\diamond \quad$ The mark for the dissertation or mini-dissertation.

$\diamond \quad$ The level of input by the supervisor during the magister programme as described by the scale in table 1 .

$\diamond \quad$ The quality of the research article reflecting the research for the magister programme as described by the scale in table 2 .

$\diamond \quad$ Undergraduate mark.

$\diamond \quad$ Mark in Research Methodology.

The following null hypotheses were formulated for the study, namely:

1. There is no relatedness between the learner's under graduate mark and the mark for the dissertation/minidissertation in the magister programme.

2. There is no relatedness between the learner's undergraduate mark and the level of input by the supervisor during the magister programme.

3. There is no relatedness between the learner's undergraduate mark and the quality of the research article produced by the learner.

4. There is no relatedness between the learner's mark in Research Methodology and the mark for the dissertation/mini-dissertation in the magister programme.

5. There is no relatedness between the learner's mark in Research Methodology and the level of input by the supervisor during the magister programme.

6. There is no relatedness between the learner's mark in Research Methodology and the quality of the research article produced by the learner.

\section{Operational definitions}

The following operational definitions are applicable for this research.

\section{Undergraduate mark}

Refers to the mark obtained in the undergraduate programme for the course that corresponds with the field of specialisation in the magister programme. If a learner does a magister in Midwifery, the final mark for the course in Midwifery will be relevant.

\section{Mark in Research Methodology}

Refers to the mark obtained for the course for Research Methodology that is compulsory for all magister programmes. The learners usually do the course in Research Methodology prior to registering for the magister programme.

\section{Achievement/success in the magister programme}

The achievement in the magister programme is reflected by 
the following components, namely:

$\diamond \quad$ The mark for the dissertation or mini-dissertation.

$\diamond \quad$ The level of input by the supervisor during the magister programme, as described by the scale in table 1 .

$\diamond \quad$ The quality of the research article reflecting the research for the magister programme as described by the scale in table 2 .

\section{Research design}

A quantitative correlational (Burns and Grove, 1993:29) design was used. The researcher adhered to the ethical standards for Nurse researchers, as described by DENOSA (1997).

\section{Data collection and population}

The following data was collected from documents of magister learners, who have completed their studies during 1990 to1997:

$\diamond \quad$ Mark of the relevant undergraduate course.

$\diamond \quad$ Mark in Research Methodology.

$\diamond \quad$ Average mark for the dissertation or mini-dissertation.

The study supervisors were asked to evaluate their input during supervision (table 1) as well as the quality of the research article (table 2) according the two scales. Data of seventyfour $(n=74)$ learners was available and complete.

\section{Table 1 Scale for the evaluation of input during study supervision}

1. Learner works independently and requires less than the normal input

2. Learner requires normal input during study supervision

3. Learner requires above normal input during study supervision, but completed the qualification within two years

4. Learner requires above normal input and takes longer than two years to complete the study

\section{Table 2 Scale for the evaluation of the research article}

1. The research article could be presented for publication without changes

2. The research article could be presented for publication with minor changes

3. The research article could be presented for publication with major changes

4. The research article is not suitable for publication.

\section{Data analysis}

The following descriptive (Burns and Grove, 1993:475478) and bivariate inferential data analysis (Burns and Grove, 1993: 509-517) were conducted, namely:

$\diamond \quad$ Descriptive statistics (measurement of central tendency and dispersion). $\diamond \quad$ Bivariate correlation with the Pearson's Productmoment correlation coefficient and the testing of the correlation coefficient.

One way analysis of variance (ANOVA)

\section{Validity and reliability}

ments, such as document triangulation were employed Grove, 1993:277).

\section{Research findings and}

Table 3 provides the data for the continuous variables, namely ptained in the undergraduate qualification, for $\mathrm{Re}$ tion. The number, minimum and maximum mark, mean and standard deviation are described. The data of 74 completed magister qualifications were accessible. The minimum range of the marks was above $50 \%$ as only successful learners formed the population. The hypotheses will be used to con-

Relatedness of the learner's undergraduate mark and the mark for the dissertation/mini-dissertation in the magister programme Table 4 shows a significant correlation $(0.414)$ at a 0.001 level between the undergraduate mark and the mark for the dissertation/minidissertation. The null hypothesis, of no correlation, can be rejected as the undergraduate mark can be used to predict success in the magister programme.

Relatedness of the learner's undergraduate mark and the level of input by the supervisor during the magister programme

Table 4 shows no significant correlation between the undergraduate mark and the level of supervision by the supervisor. This could be related to the fact that the level of supervision is not a continuous variable. Table 5 shows no differences relating to the level of supervision (refer to table 1). This implies that learners with high undergraduate marks could still require a high level of supervision. The allocation of magister learners to a supervisor does not imply that a supervisor can increase the number of learners for supervision for a specific period due of the high marks of individual learners for that period.

Relatedness of the learner's undergraduate mark and the quality of the research article produced by the learner

Table 4 shows no significant correlation between the undergraduate mark and the standard of the research article. This 
Relatedness of the learner's mark in Research Methodology and the level of input by the supervisor during the magister programme. Table 4 shows no significant correlation between the mark for Research Methodology and the level of supervision. This could be related to the fact that the level of supervision is not a continuous variable. Table 5 shows no differences between the level of supervision (refer to table 1).

Relatedness of the learner's mark in Research Methodology and the Table 4 Pearson Correlation of variables

\begin{tabular}{|l|l|l|l|}
\hline & $\begin{array}{l}\text { Dissertation/ } \\
\text { Mini-dissertation }\end{array}$ & Supervision & Research article \\
\hline Undergraduate mark & 0.414 & -0.157 & -0.065 \\
\hline Research Methodology & 0.518 & -0.253 & -0.176 \\
\hline
\end{tabular}
quality of the research article produced by the learner.

Table 4 shows no significant correlation between the mark for Research Methodology and the standard of the research article. This could be related to the fact that the standard of the research article is not a continuous variable. Table 5 shows no differences in the mark for Research Methodology and the standard of the research article (refer to table 2).

\section{Table 5 One way analysis (ANOVA) of discrete variables}

\begin{tabular}{|l|ll|}
\hline & \multicolumn{2}{|c|}{ Differences between groups in discrete data (Refer to tables $1 \& 2)$} \\
\hline Undergraduate mark & $F=1.059 \quad$ Df=3 & Significance $=0.372$ \\
\hline Research Methodology & $F=1.816 \quad$ Df=3 & Significance $=0.152$ \\
\hline
\end{tabular}

\section{Conclusions and}

\section{recommendations}

The achievement/success in the magister programme is reflected by the mark for the

\section{Table 6 Generalised Linear Model (Multivariate)}

\begin{tabular}{|l|l|}
\hline & $\begin{array}{l}\text { Linear combination of supervision input, standard of research } \\
\text { article and mark for dissertation }\end{array}$ \\
\hline Undergraduate mark & $\mathrm{F}=0.950 \quad$ Df=3 $\quad$ Significance $=0.421$ \\
\hline Research Methodology & $\mathrm{F}=3.994 \quad$ Df=3 $\quad$ Significance $=0.011$ \\
\hline
\end{tabular}

could be related to the fact that the standard of the research article is not a continuous variable. Table 5 shows no differences relating to the standard of the research article (refer to table 2).

Relatedness of the learner's mark in Research Methodology and the mark for the dissertation/mini-dissertation for the magister programme

Table 4 shows a very good correlation $(0,518)$ between the mark for Research Methodology and the mark for the dissertation/mini-dissertation ( $p$-value $=0,001$ ). The mark in Research Methodology is a better predictor of success in the magister programme (reflected by the mark in the dissertation/mini-dissertation) than the mark for the undergraduate qualification. dissertation/mini-dissertation, the level of supervision and the standard of the research article. Table 6 shows the results of the multivariate regression with the combination of the three indicators as the dependent variable and the undergraduate mark and the mark in Research Methodology as the independent variables. The result indicates that Research Methodology is the best predictor of success for the magister programme.

Based on the above evidence it can be recommended that the mark in Research Methodology should be the only criteria for selection of learners for magister programmes. Based on the literature review and empirical results the current procedure that allows a learner to do Research Methodology, prior to the registering for a magister programme, is justified. From the above evidence, it can be proposed to use a mark of $60 \%$ for Research Methodology for selection purposes.

\section{Summary}

The selection of post-graduate learners should be recognised as one of the many factors relating to problems of success, 
failure and wastage (Miller, 1970:140). It will therefore be necessary to look beyond selection in order to find possible ways of developing learners potential after selection.

\section{Bibliography}

BARNES, R 1995: Successful study for a degree. London: Routledge.

BASSON, A 1981: Studentekeuring vir graad- en diplomakursusse. Port Elizabeth: Universiteit van Port Elizabeth.

BOTES, AC \& DU PLESSIS, D 1998: Selection of B.Cur learners at the Rand Afrikaans University. A reinterpretation. Health SA Gesondheid. 3 (2), 1989: 18-22

DENOSA, 1997: Ethical standards for nurse researchers. Pretoria: Denosa.

DEPARTMENT OF NURSING, 1999: SAQA-programmes and qualifications. Johannesburg: Rand Afrikaans University.

EDDINS, D 1982: A causal model of attrition of specially admitted black learners in Higher Education. Eric document reproduction services, no. ED 224-422.

ENTWISTLE, NJ \& WILSON, JD 1977: Degrees of excellence. The academic achievement game. London: Hodder and Stoughton.

HUDSON, L 1965: Degrees Class and Attainment in Scientific Research. The Times Educational Supplement. $10^{\text {th }}$ September 1965.

TODD, OM 1987: Selected factors associated with academic success of black and white learners in urban Associated Degree Nursing Programmes ( $\mathrm{PhD}$-dissertation). Ann Abor: University of Michigan.

MILLER, GW 1970: Success, failure and wastage in Higher Education. London: The University of London Institute of Education.

ROBBINS, SP 1982: Personnel: The management of human resources. London: Prentice Hall.

WHITEHAND, JWR 1966: The selection of research learners. Universitv Ouarterly.21 (1), 1966.

WING, CW \& WALLACH, MA 1971: College admission and the psychology of talent. New York: Holt, Rinehart and Winston. 